\title{
Litorimicrobium taeanense gen. nov., sp. nov., isolated from a sandy beach
}

\author{
Hyun Mi Jin, Hyo Jung Lee, Jeong Myeong Kim, Moon Su Park, \\ Kangseok Lee and Che Ok Jeon
}

\author{
Correspondence \\ Che Ok Jeon \\ cojeon@cau.ac.kr
}

\author{
Department of Life Science and Research Center for Biomolecules and Biosystems, \\ Chung-Ang University, Seoul 156-756, Republic of Korea
}

The so-called Roseobacter clade within the class Alphaproteobacteria described by Giovannoni \& Rappé (2000) includes cultivated and uncultivated micro-organisms found in marine environments all over the world (Buchan et al., 2005; Martens et al., 2006). Members of the Roseobacter clade have been isolated from various marine habitats such as a tidal flat, marine electroactive biofilms, the Arctic Ocean and the phycosphere of a dinoflagellate (Lafay et al., 1995; Yoon et al., 2007; Zhang et al., 2008; Vandecandelaere et al., 2008, 2009). Characterization of such isolates has demonstrated that they are physiologically and metabolically diverse with characteristics such as the ability to grow on methyl bromide (Schaefer et al., 2002), aerobic anoxygenic phototrophy (Shiba, 1991), aerobic sulfite oxidation (Moran et al., 2003) and aromatic monomers degradation (Buchan et al., 2000). Coastal seashores play very important roles in the restoration of ecosystems, micro-organisms and marine animals being

Abbreviations: AL, aminolipid; DPG, diphosphatidylglycerol; L, lipid; $M L$, maximum-likelihood; MP, maximum-parsimony; $\mathrm{NJ}$, neighbour-joining; PC, phosphatidylcholine; PG, phosphatidylglycerol; PL, phospholipid; RFLP, restriction fragment length polymorphism.

The GenBank/EMBL/DDBJ accession number for the 16S rRNA gene sequence of strain $\mathrm{G} 4^{\top}$ is $\mathrm{GQ} 232737$.

Three supplementary figures and one supplementary table are available with the online version of this paper. valuable biological resources. Therefore, efforts have been made to isolate and characterize members of the bacterial community of the seashore of the Yellow Sea in South Korea (Kim et al., 2010). Here we describe the taxonomic characterization of a novel species of a novel genus belonging to the family Rhodobacteraceae, isolated from a sandy beach of the Yellow Sea in Korea.

Strain $4^{\mathrm{T}}$ was isolated from a sandy beach of Taean $\left(36^{\circ} 48^{\prime}\right.$ $\left.50^{\prime \prime} \mathrm{N} 126^{\circ} 11^{\prime} 9^{\prime \prime} \mathrm{E}\right)$ in the Yellow Sea, South Korea, by using a previously described procedure (Kim et al., 2008) with some modifications. Briefly, a sand sample was dispersed in $0.9 \%(\mathrm{w} / \mathrm{v})$ saline and serially diluted in 10 -fold steps by adding $1 \mathrm{ml}$ of the previous dilution to $9 \mathrm{ml}$ saline. The diluted suspensions were spread on marine agar 2216 (MA; Difco) and incubated under aerobic conditions at $25{ }^{\circ} \mathrm{C}$ for 5 days. Colonies were selected at random and crude genomic DNA from respective colonies was prepared as described previously (Lu et al., 2006). PCR amplification of $16 \mathrm{~S}$ rRNA genes was performed using universal primers, F1 (5'-AGAGTTTGATCMTGGCTCAG-3') and R13 (5'-TACGGYTACCTTGTTACGACTT- $3^{\prime}$ ). The amplicons were double-digested with HaeIII and HhaI. Restriction fragment length polymorphism (RFLP) patterns were analysed on $2.5 \%$ MetaPhore agarose (BioWhittaker, USA) gels and colonies were grouped according to their RFLP patterns. Representative PCR products containing distinct RFLP 
patterns were sequenced. The resulting 16S rRNA gene sequences were analysed using the BLAST program (http:// blast.ncbi.nlm.nih.gov/Blast.cgi) in GenBank. From the analysis, a novel strain belonging to the family Rhodobacteraceae, designated strain $\mathrm{G4}^{\mathrm{T}}$, was selected for additional phenotypic and phylogenetic analysis. The strain was routinely grown aerobically on MA at $30{ }^{\circ} \mathrm{C}$ for 3 days, unless otherwise indicated. The strain was stored at $-80{ }^{\circ} \mathrm{C}$ in marine broth (Difco) supplemented with $10 \%(\mathrm{v} / \mathrm{v})$ glycerol for preservation. Phaeobacter gallaeciensis $\mathrm{BS} 107^{\mathrm{T}}$ and Leisingera methylohalidivorans DSM $14336^{\mathrm{T}}$ (purchased from DSMZ, Germany), Marinovum algicola DSM $10251^{\mathrm{T}}$ (purchased from KCTC, Korea) and Leisingera nanhaiensis NH52 $\mathrm{F}^{\mathrm{T}}$ (purchased from BCCM/LMG, Belgium) were used as reference strains for phenotypic characterization and fatty acid analysis.

The 16S rRNA gene sequence (1386 nt) of strain $\mathrm{G} 4^{\mathrm{T}}$ was checked manually for quality and for gaps. Sequence similarity values between the novel isolate and closely related bacteria were evaluated using the Nucleotide Similarity Search program in the EzTaxon server 2.1 (http://147.47.212.35:8080/; Chun et al., 2007) and aligned by using the CLUSTAL W program (Thompson et al., 1994). Phylogenetic trees were reconstructed using the neighbourjoining (NJ) and maximum-parsimony (MP) algorithms in PHYLIP version 3.6 software (Felsenstein, 2002). Tree topology was evaluated using bootstrap analysis based on 1000 resampled datasets. Maximum-likelihood (ML) analysis with bootstrap support was performed using RAxMLHPC in Abe (version 7.2.6) of the Cyberinfrastructure for Phylogenetic Research project (CIPRES, www.phylo.org) at the San Diego Supercomputer Center.

Comparative analysis of $16 \mathrm{~S}$ rRNA gene sequences showed that strain $\mathrm{G}^{\mathrm{T}}$ was closely related to Phaeobacter gallaeciensis $\mathrm{BS} 107^{\mathrm{T}}$, Phaeobacter inhibens $\mathrm{T}^{\mathrm{T}}$, Leisingera nanhaiensis $\mathrm{NH}_{5} \mathrm{~F}^{\mathrm{T}}$, Phaeobacter arcticus $20188^{\mathrm{T}}$ and Marinovum algicola ATCC $51440^{\mathrm{T}}$ with similarities of 96.6, 96.5, 96.1, 95.6 and 95.6\%, respectively. Phylogenetic analysis based on $16 \mathrm{~S}$ rRNA gene sequences indicated that strain $\mathrm{G} 4^{\mathrm{T}}$ formed a phyletic lineage with Leisingera nanhaiensis $\mathrm{NH}_{52} \mathrm{~F}^{\mathrm{T}}$ with a relatively low bootstrap value (65\%) within the family Rhodobacteraceae (Fig. 1). However, strain $\mathrm{G} 4^{\mathrm{T}}$ formed a clear distinct phylogenetic lineage from other type strains of the genus Leisingera including the type species of the genus, $L$. methylohalidivorans $\mathrm{NB}^{\mathrm{T}}$. The topology of phylogenetic trees reconstructed using the MP and ML algorithms also supported the distinct lineage from related taxa (Supplementary Fig. S1, available in IJSEM Online). In addition, analysis using the Ribosomal Database Project (RDP) classifier program (Wang et al., 2007) showed that there was no genus group with a clear phylogenetic relationship to strain $\mathrm{G}^{\mathrm{T}}{ }^{\mathrm{T}}$ within the family Rhodobacteraceae.

Growth of strain $\mathrm{G} 44^{\mathrm{T}}$ at $5-45{ }^{\circ} \mathrm{C}\left(5{ }^{\circ} \mathrm{C}\right.$ intervals $)$ and pH 5-10 (intervals of $0.5 \mathrm{pH}$ units) was determined on MA agar and in marine broth, respectively. Media with

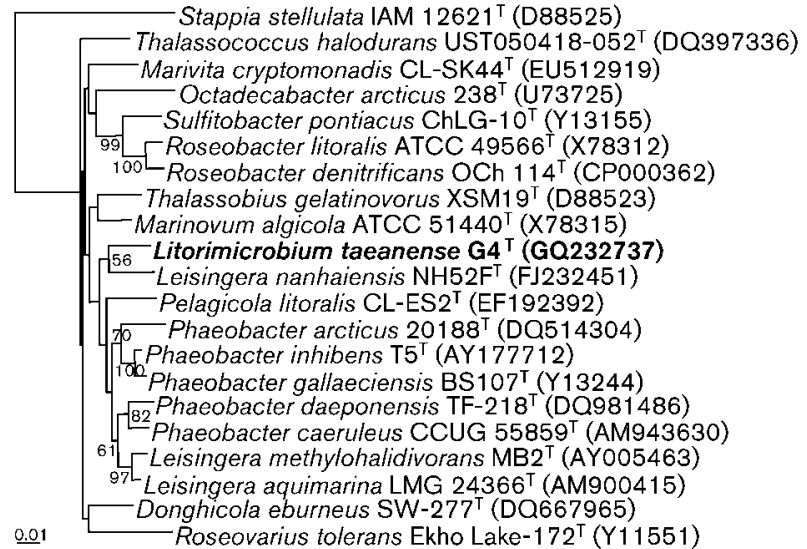

Fig. 1. Neighbour-joining tree based on 16S rRNA gene sequences showing the phylogenetic relationship between strain $\mathrm{G} 4^{\top}$ and closely related taxa. Bootstrap values $>50 \%$, based on 1000 replicates, are shown at branch points. Stappia stellulata IAM $12621^{\top}$ was used as an outgroup. Bar, 0.01 substitutions per nucleotide position.

different $\mathrm{pH}$ values were prepared using appropriate biological buffers. $\mathrm{Na}_{2} \mathrm{HPO}_{4}-\mathrm{NaH}_{2} \mathrm{PO}_{4}$ buffer, $\mathrm{Na}_{2} \mathrm{CO}_{3}-$ $\mathrm{NaHCO}_{3}$ buffer and $\mathrm{Na}_{2} \mathrm{HPO}_{4}-\mathrm{NaOH}$ buffer were used for $\mathrm{pH}$ values of below $8, \mathrm{pH} 8-10$ and $\mathrm{pH} 11$, respectively (Gomori, 1955). pH levels were checked again after sterilization. Gram staining was performed using a bioMérieux Gram Stain kit according to the manufacturer's instructions. Cell morphology and the presence of flagella were determined using phase-contrast microscopy and transmission electron microscopy (JEM-1010, JEOL) with 2-day-old cells grown on MA as described previously (Jeon et al., 2004). Requirement and tolerance of $\mathrm{NaCl}$ were determined in nutrient broth (NB: $3.0 \mathrm{~g}$ beef extract and $5.0 \mathrm{~g}$ peptone per litre) supplemented with modified artificial seawater [ASW: $0-15 \%(\mathrm{w} / \mathrm{v}) \mathrm{NaCl}$ at $0.5 \%$ intervals, $5.94 \mathrm{~g} \mathrm{MgSO}_{4} .7 \mathrm{H}_{2} \mathrm{O}, 4.53 \mathrm{~g} \mathrm{MgCl}_{2} .6 \mathrm{H}_{2} \mathrm{O}$, $0.64 \mathrm{~g} \mathrm{KCl}$ and $1.3 \mathrm{~g} \mathrm{CaCl}_{2}$ per litre] (Kahng et al., 2009). Oxidase activity was tested by oxidation of $1 \%$ $(\mathrm{w} / \mathrm{v})$ tetramethyl-p-phenylenediamine (Merck) and catalase activity was evaluated by the production of oxygen bubbles in $3 \%(\mathrm{v} / \mathrm{v})$ aqueous hydrogen peroxide solution (Smibert \& Krieg, 1994). Antibiotic susceptibility tests were performed in duplicate using filter-paper discs (diameter, $8 \mathrm{~mm}$ ) containing the following antibiotics ( $\mu \mathrm{g}$ per disc unless stated otherwise): ampicillin (10), polymyxin B (100 IU), streptomycin (50), penicillin G (10 IU), gentamicin (30), chloramphenicol (100), tetracycline (30), kanamycin (30), lincomycin (15), oleandomycin (15), carbenicillin (100) and novobiocin (50). Additional enzymic activities and biochemical features were determined using API ZYM and API 20 NE kits (bioMérieux) according to the manufacturer's instructions except that the inocula were prepared by suspending cells in a $3 \%(\mathrm{w} / \mathrm{v}) \mathrm{NaCl}$ solution. Anaerobic growth was assessed by incubating on MA under 
anaerobic conditions $\left(4-10 \% \mathrm{CO}_{2}\right)$ using a GasPak Plus system (BBL) at $30{ }^{\circ} \mathrm{C}$ for 20 days.

Strain $\mathrm{G} 4{ }^{\mathrm{T}}$ grew at $15-35{ }^{\circ} \mathrm{C}$ (optimum $25-30{ }^{\circ} \mathrm{C}$ ) but not at 10 or $37^{\circ} \mathrm{C}$. The novel strain also grew at $\mathrm{pH} 6-8$ (optimum $\mathrm{pH}$ 6.5-7.5) on $\mathrm{MA}$ at $30^{\circ} \mathrm{C}$ and in $\mathrm{NB}$ supplemented with modified artificial seawater containing $1-6 \%(\mathrm{w} / \mathrm{v}) \mathrm{NaCl}$ (optimum 2-4\% $\mathrm{NaCl}$ ). Cells of strain $\mathrm{G}^{\mathrm{T}}{ }^{\mathrm{T}}$ were Gram-reaction-negative, non-motile, ovoid rods, $0.8-1.2 \times 1.2-1.8 \mu \mathrm{m}$ in size (Supplementary Fig. S2). The motility of these cells clearly differentiated strain $\mathrm{G} 4^{\mathrm{T}}$ from closely related members of the genera Leisingera, Phaeobacter and Marinovum (Table 1). Physiological and biochemical characteristics of strain $\mathrm{G} 4^{\mathrm{T}}$ are shown in Table 1 and in the species description.

The DNA $\mathrm{G}+\mathrm{C}$ content of strain $\mathrm{G} 4^{\mathrm{T}}$ was determined using reversed-phase HPLC (GROM-SIL 100 ODS-2FE, GROM) according to the method of Tamaoka \& Komagata (1984). Fatty acid methyl esters were extracted from cells of strain $\mathrm{G} 4^{\mathrm{T}}$ grown on MA plates at $30{ }^{\circ} \mathrm{C}$ for 3 days and analysed according to the instructions of the Sherlock Microbial Identification System (MIDI). For isoprenoid quinone and polar lipid analyses, cells of strain $\mathrm{G} 4^{\mathrm{T}}$ were cultivated in marine broth at $30{ }^{\circ} \mathrm{C}$ for 3 days and then harvested by centrifugation. Isoprenoid quinones were analysed using a HPLC (model LC-20A, Shimadzu) equipped with a diode array detector (SPD-M20A, Shimadzu $)$ and a reversed-phase column $(250 \times 4.6 \mathrm{~mm}$, AkzoNobel-Kromasil) as described previously (Komagata \& Suzuki, 1987). Polar lipids were determined by TLC as described by Minnikin et al. (1977). The major respiratory lipoquinone of strain $\mathrm{G} 4^{\mathrm{T}}$ was ubiquinone $10(\mathrm{Q}-10)$. The DNA G $+C$ content of strain $\mathrm{G}^{\mathrm{T}}$ was $62.4 \mathrm{~mol} \%$. The major cellular fatty acids were $\mathrm{C}_{18: 1} \omega 7 c(59.0 \%), \mathrm{C}_{18: 1} \omega 7 c$ 11-methyl (11.3\%), $\mathrm{C}_{12: 1} \quad 3-\mathrm{OH} \quad(9.8 \%), \mathrm{C}_{16: 0} \quad 2-\mathrm{OH}$ (7.3\%), $\mathrm{C}_{16: 0}(5.8 \%)$, unknown $11.799(5.4 \%)$ and $\mathrm{C}_{18: 0}$ $(1.3 \%)$. Strain $\mathrm{G}^{\mathrm{T}}$ and closely related species contained $\mathrm{C}_{18: 1} \omega 7 \mathrm{c}$ as the predominant fatty acid, which is a feature of the majority of species within the class Alphaproteobacteria (Martens et al., 2006), but the presence of $\mathrm{C}_{12: 1} 3-\mathrm{OH}$ and the absence of $\mathrm{C}_{10: 0} 3-\mathrm{OH}$ and $\mathrm{C}_{12: 0} 3-\mathrm{OH}$ clearly differentiated the novel isolate from closely related members of the genera Leisingera, Phaeobacter and Marinovum (Table 2). The major cellular polar lipids were identified as phosphatidylglycerol (PG), diphosphatidylglycerol (DPG), phosphatidylcholine (PC), an unidentified amino lipid $(\mathrm{AL})$, an unidentified phospholipid (PL) and unidentified lipid (L) (Supplementary Fig. S3). Strain $\mathrm{G} 4^{\mathrm{T}}$ contained PC, which distinguished the isolate from members of the genus Leisingera (Table 1). Based on physiological, biochemical and phylogenetic properties, strain $G 4^{\mathrm{T}}$ represents a novel species of a novel genus within the

Table 1. Phenotypic characteristics of strain $\mathrm{G} 4^{\top}$ and related species of the genera Leisingera, Phaeobacter and Marinovum

Strains: 1, G4 ${ }^{\mathrm{T}}$ (data from this study); 2, Leisingera nanhaiensis LMG $24841^{\mathrm{T}}$ (Sun et al., 2010); 3, Leisingera methylohalidivorans DSM $14336^{\mathrm{T}}$ (Schaefer et al., 2002; Martens et al., 2006; Vandecandelaere et al., 2008); 4, Phaeobacter gallaeciensis DSM 17395 ${ }^{\mathrm{T}}$ (Martens et al., 2006; Vandecandelaere et al., 2009); 5. Marinovum algicola DSM $10251^{\mathrm{T}}$ (Lafay et al., 1995; Ruiz-Ponte et al., 1998). All strains were positive for the following characteristics: esterase (C4), leucine arylamidase, valine arylamidase and acid phosphatase activities (API ZYM) and growth in $1 \%$ (w/v) $\mathrm{NaCl}$. All strains were negative for Gram-reaction and nitrate reduction. +, Positive; -, negative; $(+)$, weakly positive.

\begin{tabular}{|c|c|c|c|c|c|}
\hline Characteristic & 1 & 2 & 3 & 4 & 5 \\
\hline Morphology & Ovoid rods & Rods/ovoid rods & Rods/ovoid rods & Ovoid rods & Rods/ovoid rods \\
\hline Colony colour & Creamy & Beige & Non-pigmented & Brown & Beige-pinkish-beige \\
\hline Motility & - & + & + & + & + \\
\hline \multicolumn{6}{|l|}{ Growth at/in: } \\
\hline $4{ }^{\circ} \mathrm{C}$ & - & + & $(+)$ & - & - \\
\hline $37^{\circ} \mathrm{C}$ & - & $(+)$ & - & + & + \\
\hline $7 \%(\mathrm{w} / \mathrm{v}) \mathrm{NaCl}$ & - & - & + & + & + \\
\hline \multicolumn{6}{|l|}{ Degradation of: ${ }^{\star}$} \\
\hline Aesculin & $(+)$ & + & - & + & + \\
\hline Gelatin & - & + & - & - & + \\
\hline \multicolumn{6}{|l|}{ Enzyme activity ${ }^{\star}$} \\
\hline$\alpha$-Chymotrypsin & - & + & $(+)$ & $(+)$ & + \\
\hline$\alpha$-Galactosidase & $(+)$ & + & - & $(+)$ & + \\
\hline$\beta$-Galactosidase & $(+)$ & $(+)$ & - & $(+)$ & + \\
\hline $\begin{array}{l}\text { Naphthol-AS-B1- } \\
\text { phosphohydrolase }\end{array}$ & - & + & $(+)$ & $(+)$ & $(+)$ \\
\hline Polar lipids & $\begin{array}{c}\text { PG, DPG, PC, } \\
\text { AL, PL, L }\end{array}$ & $\begin{array}{c}\text { PG, PE, PL, L, } \\
\text { AL }\end{array}$ & $\begin{array}{c}\text { PG, PE, PL, L } \\
\text { AL }\end{array}$ & $\begin{array}{c}\text { PC, PG, PE, L, } \\
\text { AL, PL }\end{array}$ & $\begin{array}{c}\text { PC, PG, PE, L, } \\
\text { AL, PL }\end{array}$ \\
\hline DNA G $+C$ content $(\mathrm{mol} \%)$ & 62.4 & 60.5 & 60.5 & 58.0 & 60.0 \\
\hline
\end{tabular}

${ }^{\star}$ Results from this study. 
Table 2. Cellular fatty acid compositions (\%) of strain $\mathrm{G}^{\top}{ }^{\top}$ and related members of the genera Leisingera, Phaeobacter and Marinovum

Strains: $1, \mathrm{G}^{\mathrm{T}} ; 2$, Leisingera nanhaiensis LMG $24841^{\mathrm{T}} ; 3$, Leisingera methylohalidivorans DSM $14336^{\mathrm{T}} ; 4$, Phaeobacter gallaeciensis DSM $17395^{\mathrm{T}}$; 5, Marinovum algicola DSM $10251^{\mathrm{T}}$. All data from this study. Data are expressed as percentages of total fatty acids. Fatty acids $<0.5 \%$ not shown. ECL, Equivalent chain-length; -, not detected.

\begin{tabular}{|lccccc|}
\hline Fatty acid & $\mathbf{1}$ & $\mathbf{2}$ & $\mathbf{3}$ & $\mathbf{4}$ & $\mathbf{5}$ \\
\hline Saturated & & & & & \\
$\mathrm{C}_{12: 0}$ & - & 1.0 & 1.9 & 1.4 & - \\
$\mathrm{C}_{16: 0}$ & 5.8 & 3.6 & 3.4 & 8.6 & 3.4 \\
$\mathrm{C}_{18: 0}$ & 1.3 & 0.9 & - & 1.8 & 2.3 \\
Hydroxy & & & & & \\
$\mathrm{C}_{10: 0} 3-\mathrm{OH}$ & - & 9.4 & 6.5 & 7.8 & 1.6 \\
$\mathrm{C}_{12: 0} 3-\mathrm{OH}$ & - & 4.5 & 6.4 & 4.7 & 1.6 \\
$\mathrm{C}_{12: 1} 3-\mathrm{OH}$ & 9.8 & - & - & - & 0.9 \\
$\mathrm{C}_{16: 0} 2-\mathrm{OH}$ & 7.3 & 8.0 & 10.3 & 5.6 & - \\
Unsaturated & & & & & \\
$\mathrm{C}_{17: 1} \omega 8 c$ & - & - & - & - & 1.1 \\
$\mathrm{C}_{18: 1} \omega 7 c$ & 59.0 & 59.5 & 58.1 & 56.4 & 77.5 \\
$\mathrm{C}_{18: 1} \omega 7 c$ 11-methyl & 11.3 & 3.6 & 3.5 & 6.0 & 8.6 \\
$\mathrm{C}_{19: 0} 10-\mathrm{methyl}$ & - & - & - & - & 0.5 \\
Branched & & & & & \\
anteiso-C & & - & - & - & 0.7 \\
iso-C $\mathrm{C}_{17: 1} \omega 9 \mathrm{c}$ & - & - & - & - & 0.5 \\
Unknown ECL 11.799 & 5.4 & 7.8 & 9.9 & 7.9 & - \\
Summed feature $4 *$ & - & 1.7 & - & - & - \\
& & & & & \\
\hline
\end{tabular}

${ }^{*}$ Summed features represent groups of two or three fatty acids that could not be separated by GLC with the MIDI system. Summed feature 4 comprised iso- $\mathrm{C}_{17: 1} \mathrm{I}$ and/or anteiso- $\mathrm{C}_{17: 1} \mathrm{~B}$.

family Rhodobacteraceae of the class Alphaproteobacteria, for which the name Litorimicrobium taeanense gen. nov., sp. nov. is proposed.

\section{Description of Litorimicrobium gen. nov.}

Litorimicrobium (Li.to.ri.mi.cro'bi.um. L. n. litus -oris sand beach; N.L. neut. n. microbium microbe; N.L. neut. n. Litorimicrobium microbe living in a sand beach).

Cells are Gram-reaction-negative, non-motile, ovoid rods. Oxidase- and catalase-positive. Nitrate is reduced to nitrite. The isoprenoid quinone detected is Q-10. The predominant fatty acid is $\mathrm{C}_{18: 1} \omega 7 \mathrm{c}$. The major cellular polar lipids are PG, DPG, PC, an unidentified AL, an unidentified PL and an unidentified $\mathrm{L}$. The major cellular fatty acids are $\mathrm{C}_{18: 1} \omega 7 c, \mathrm{C}_{18: 1} \omega 7 c$ 11-methyl, $\mathrm{C}_{12: 1} 3-\mathrm{OH}, \mathrm{C}_{16: 0} 2-\mathrm{OH}$, $\mathrm{C}_{16: 0}$ and unknown ECL 11.799. Phylogenetically, the genus belongs to the family Rhodobacteraceae of the class Alphaproteobacteria. The type species is Litorimicrobium taeanense. The DNA G $+\mathrm{C}$ content of the type strain of the type species is $62.4 \mathrm{~mol} \%$ (HPLC).

\section{Description of Litorimicrobium taeanense sp. nov.}

Litorimicrobium taeanense (ta.e.a.nen'se. N.L. neut. adj. taeanense of or belonging to Taean, from where the organism was isolated).

In addition to the characters described for the genus, the species is characterized by the following properties. Cells are strictly aerobic and $0.8-1.2 \times 1.2-1.8 \mu \mathrm{m}$. Colonies on MA are creamy white, convex and round with entire margins. Growth occurs at $15-35{ }^{\circ} \mathrm{C}$ (optimum $25-30{ }^{\circ} \mathrm{C}$ ) and $\mathrm{pH}$ 6-8 (optimum $\mathrm{pH}$ 6.5-7.5). Aesculin and urea are hydrolysed. Gelatin is not hydrolysed. Negative for assimilation of D-glucose, L-arabinose, D-mannose, maltose, D-mannitol, malic acid, potassium gluconate, $\mathrm{N}$ acetylglucosamine, capric acid, adipic acid, trisodium citrate and phenylacetic acid (API $20 \mathrm{NE}$ ). Positive for esterase (C4), esterase lipase (C8), leucine arylamidase, valine arylamidase and acid phosphatase activities but negative for $\alpha$-chymotrypsin, $\alpha$-glucosidase, $\beta$-glucuronidase, $N$-acetyl- $\beta$-glucosaminidase, $\alpha$-mannose and $\alpha$-fucosidase activities. Weakly positive for lipase (C14), trypsin, alkaline phosphatase, cystine arylamidase, $\alpha$-galactosidase, $\beta$-galactosidase, $\beta$-glucosidase and naphthol-AS-B1-phosphohydrolase activities (API ZYM). The major isoprenoid quinone is Q-10. Resistant to polymyxin B, gentamicin, kanamycin, novobiocin, oleandomycin, lincomycin, ampicillin, tetracycline and carbenicillin but sensitive to streptomycin, penicillin $\mathrm{G}$ and chloramphenicol.

The type strain, $\mathrm{G} 4^{\mathrm{T}}\left(=\mathrm{KACC} 13703^{\mathrm{T}}=\right.$ DSM $\left.22007^{\mathrm{T}}\right)$, was isolated from a sandy beach of the coast of Taean, South Korea. The DNA G+C content of the type strain is $62.4 \mathrm{~mol} \%$ (HPLC).

\section{Acknowledgements}

These efforts were supported by a grant from the MOST/KOSEF to the 21C Frontier Microbial Genomics and Application Center Program (no. MG05-0104-4-0) and a grant from the National Research Foundation of Korea (no. 2009-0071880), funded by the Korean Government (MEST).

\section{References}

Buchan, A., Collier, L. S., Neidle, E. L. \& Moran, M. A. (2000). Key aromatic-ring-cleaving enzyme, protocatechuate 3,4-dioxygenase, in the ecologically important marine Roseobacter lineage. Appl Environ Microbiol 66, 4662-4672.

Buchan, A., González, J. M. \& Moran, M. A. (2005). Overview of the marine Roseobacter lineage. Appl Environ Microbiol 71, 56655677.

Chun, J., Lee, J. H., Jung, Y., Kim, M., Kim, S., Kim, B. K. \& Lim, Y. W. (2007). EzTaxon: a web-based tool for the identification of prokaryotes based on 16S ribosomal RNA gene sequences. Int J Syst Evol Microbiol 57, 2259-2261.

Felsenstein, J. (2002). PHYLIP (phylogeny inference package), version 3.6a. Distributed by the author. Department of Genome Sciences, University of Washington, Seattle, USA. 
Giovannoni, S. J. \& Rappé, M. (2000). Evolution, diversity, and molecular ecology of marine prokaryotes. In Microbial Ecology of the Oceans, pp. 47-84. Edited by D. L. Kirchman. New York: Wiley.

Gomori, G. (1955). Preparation of buffers for use in enzyme studies. Methods Enzymol 1, 138-146.

Jeon, C. O., Park, W., Ghiorse, W. C. \& Madsen, E. L. (2004). Polaromonas naphthalenivorans sp. nov., a naphthalene-degrading bacterium from naphthalene-contaminated sediment. Int J Syst Evol Microbiol 54, 93-97.

Kahng, H.-Y., Chung, B. S., Lee, D.-H., Jung, J.-S., Park, J. H. \& Jeon, C. O. (2009). Cellulophaga tyrosinoxydans sp. nov., a tyrosinaseproducing bacterium isolated from seawater. Int J Syst Evol Microbiol 59, 654-657.

Kim, J. M., Le, N. T., Chung, B. S., Park, J. H., Bae, J.-W., Madsen, E. L. \& Jeon, C. O. (2008). Influence of soil components on the biodegradation of benzene, toluene, ethylbenzene, and $o^{-}, m^{-}$, and $p$-xylenes by the newly isolated bacterium Pseudoxanthomonas spadix BD-a59. Appl Environ Microbiol 74, 7313-7320.

Kim, J. M., Lee, S. H., Jung, J. Y. \& Jeon, C. O. (2010). Marinobacterium lutimaris sp. nov., isolated from a tidal flat. Int $J$ Syst Evol Microbiol 60, 1828-1831.

Komagata, K. \& Suzuki, K. (1987). Lipid and cell-wall analysis in bacterial systematics. Methods Microbiol 19, 161-207.

Lafay, B., Ruimy, R., de Traubenberg, C. R., Breittmayer, V., Gauthier, M. J. \& Christen, R. (1995). Roseobacter algicola sp. nov., a new marine bacterium isolated from the phycosphere of the toxinproducing dinoflagellate Prorocentrum lima. Int J Syst Bacteriol 45, 290-296.

Lu, S., Park, M., Ro, H.-S., Lee, D. S., Park, W. \& Jeon, C. O. (2006). Analysis of microbial communities using culture-dependent and culture-independent approaches in an anaerobic/aerobic SBR reactor. J Microbiol 44, 155-161.

Martens, T., Heidorn, T., Pukall, R., Simon, M., Tindall, B. J. \& Brinkhoff, T. (2006). Reclassification of Roseobacter gallaeciensis RuizPonte et al. 1998 as Phaeobacter gallaeciensis gen. nov., comb. nov., description of Phaeobacter inhibens sp. nov., reclassification of Ruegeria algicola (Lafay et al. 1995) Uchino et al. 1999 as Marinovum algicola gen. nov., comb. nov., and emended descriptions of the genera Roseobacter, Ruegeria and Leisingera. Int J Syst Evol Microbiol 56, 1293-1304.

Minnikin, D. E., Patel, P. V., Alshamaony, L. \& Goodfellow, M. (1977). Polar lipid composition in the classification of Nocardia and related bacteria. Int J Syst Bacteriol 27, 104-117.

Moran, M. A., Gonzalez, J. M. \& Kiene, R. P. (2003). Linking a bacterial taxon to sulfur cycling in the sea: studies of the marine Roseobacter group. Geomicrobiol J 20, 375-388.
Ruiz-Ponte, C., Cilia, V., Lambert, C. \& Nicolas, J. L. (1998). Roseobacter gallaeciensis sp. nov., a new marine bacterium isolated from rearings and collectors of the scallop Pecten maximus. Int J Syst Bacteriol 48, 537-542.

Schaefer, J. K., Goodwin, K. D., McDonald, I. R., Murrell, J. C. \& Oremland, R. S. (2002). Leisingera methylohalidivorans gen. nov., sp. nov., a marine methylotroph that grows on methyl bromide. Int J Syst Evol Microbiol 52, 851-859.

Shiba, T. (1991). Roseobacter litoralis gen. nov., sp. nov., and Roseobacter denitrificans sp. nov., aerobic pink-pigmented bacteria which contain bacteriochlorophyll a. Syst Appl Microbiol 14, 140145.

Smibert, R. M. \& Krieg, N. R. (1994). Phenotypic characterization. In Methods for General and Molecular Bacteriology, pp. 607-654. Edited by P. Gerhardt. Washington, DC: American Society for Microbiology.

Sun, F., Wang, B., Liu, X., Lai, Q., Du, Y., Li, G., Luo, J. \& Shao, Z. (2010). Leisingera nanhaiensis sp. nov., isolated from marine sediment. Int J Syst Evol Microbiol 60, 275-280.

Tamaoka, J. \& Komagata, K. (1984). Determination of DNA base composition by reversed-phase high-performance liquid chromatography. FEMS Microbiol Lett 25, 125-128.

Thompson, J. D., Higgins, D. G. \& Gibson, T. J. (1994). CLUSTAL W: improving the sensitivity of progressive multiple sequence alignment through sequence weighting, position-specific gap penalties and weight matrix choice. Nucleic Acids Res 22, 4673-4680.

Vandecandelaere, I., Segaert, E., Mollica, A., Faimali, M. \& Vandamme, P. (2008). Leisingera aquimarina sp. nov., isolated from a marine electroactive biofilm, and emended descriptions of Leisingera methylohalidivorans Schaefer et al. 2002, Phaeobacter daeponensis Yoon et al. 2007 and Phaeobacter inhibens Martens et al. 2006. Int J Syst Evol Microbiol 58, 2788-2793.

Vandecandelaere, I., Segaert, E., Mollica, A., Faimali, M. \& Vandamme, P. (2009). Phaeobacter caeruleus sp. nov., a bluecoloured, colony-forming bacterium isolated from a marine electroactive biofilm. Int J Syst Evol Microbiol 59, 1209-1214.

Wang, Q., Garrity, G. M., Tiedje, J. M. \& Cole, J. R. (2007). Naive Bayesian classifier for rapid assignment of rRNA sequences into the new bacterial taxonomy. Appl Environ Microbiol 73, 5261-5267.

Yoon, J. H., Kang, S. J., Lee, S. Y. \& Oh, T. K. (2007). Phaeobacter daeponensis sp. nov., isolated from a tidal flat of the Yellow Sea in Korea. Int J Syst Evol Microbiol 57, 856-861.

Zhang, D. C., Li, H. R., Xin, Y. H., Liu, H. C., Chi, Z. M., Zhou, P. J. \& Yu, Y. (2008). Phaeobacter arcticus sp. nov., a psychrophilic bacterium isolated from the Arctic. Int J Syst Evol Microbiol 58, 13841387. 